\title{
En los márgenes de la creación: Miguel de Perea y el mercado de escultura en Sevilla durante el reinado de Felipe V*
}

\author{
Working on the fringes: Miguel de Perea and the sculpture market in \\ Seville during the reign of Philip V
}

\section{Manuel García Luque ${ }^{1}$}

Universidad de Sevilla

Resumen: El artículo aborda el estudio del escultor y ensamblador sevillano Miguel de Perea Ahumada (1680-ca. 1743), más conocido por ser el maestro del escultor Benito de Hita y Castillo. El hallazgo de nuevas fuentes inéditas y la recopilación de algunas otras dispersas nos permite realizar una primera aproximación biográfica. Asimismo, su figura es analizada en el contexto de la escultura sevillana de la primera mitad del siglo XVIII, donde el creciente protagonismo del taller de Pedro Duque Cornejo acabaría precipitando la marcha de maestros como Perea a otros focos creativos.

Palabras clave: Miguel de Perea, escultura, retablo, Sevilla, Granada, siglo XVIII.

Abstract: This paper focuses on the Sevillian sculptor and assembler Miguel de Perea Ahumada (1680-ca. 1743), best known for being the master of the sculptor Benito de Hito y Castillo. A new biographical approach is presented, based on new documentary sources and some news scattered in the bibliography. Furthermore, his figure is analyzed in the context of Sevillian sculpture of the first half of the $18^{\text {th }}$ century, where the raising of the workshop of Pedro Duque Cornejo precipitated the migration of masters such as Perea to other artistic centers.

Keywords: Miguel de Perea, sculpture, altarpiece, Seville, Granada, 18th century.

1 ๑https://orcid.org/0000-0001-9795-5679

(C) 2020 Philostrato. Revista de Historia y Arte 


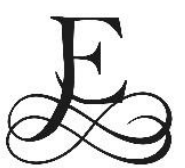

I de Miguel de Perea Ahumada (Sevilla, 1680- ¿Granada?, ca. 1743) es un caso arquetípico de maestro secundario cuya obra apenas ha dejado huella en la historiografía artística. A su desafortunada trayectoria como escultor, desarrollada a la sombra del gran astro de la escultura sevillana del momento, su contemporáneo Pedro Duque Cornejo (1678-1757), hay que sumar el hecho de que buena parte de su producción documentada haya desaparecido o permanezca todavía sin identificar. Ambas circunstancias explicarían el general olvido que ha experimentado su figura en las historias de la escultura sevillana, donde únicamente aparece recordado en su condición de hijo y discípulo del malagueño Agustín de Perea (ca. 1658-1701) o, en el mejor de los casos, como maestro de Benito de Hita y Castillo (1714-1784).

Tanto su ascendencia artística como su magisterio sobre Hita son dos aspectos de su biografía que ya fueron tempranamente señalados por Ceán Bermúdez ${ }^{2}$, y que las investigaciones del siglo XX pudieron corroborar documentalmente ${ }^{3}$. Sin embargo, ni el ilustrado asturiano ni sus informantes sevillanos fueron capaces de señalar ni una sola escultura de Perea. La maldición de ser un autor sin obra ha pervivido prácticamente hasta nuestros días. Tan solo la identificación, en las últimas décadas, del Jesús Nazareno de Baena ${ }^{4}$ y del tondo pétreo del Salvador que corona la portada de la basílica de San Juan de Dios de Granada ${ }^{5}$, ha permitido realizar un primer acercamiento al estilo de Perea en su etapa madura, constatando su versatilidad como escultor en piedra y en madera, y documentando su paso por la localidad cordobesa de Castro del Río y la ciudad de Granada.

Partiendo de una serie de noticias dispersas y de abundantes fuentes inéditas, en este trabajo trataremos de recomponer la trayectoria artística de esta olvidada figura de la escultura sevillana del siglo XVIII, centrándonos es pecialmente en su fase sevillana, que abarca desde su nacimiento hasta su marcha de la ciudad en torno a 1730.

\footnotetext{
* Este trabajo ha sido realizado en el marco del proyecto "Barroco entre dos mundos: relaciones y alternativas en la escultura andaluza e hispanoamericana entre 1700 y 1750" (HAR2017-83017P), financiado por el Ministerio de Economía y Competitividad. Deseo expresar mi agradecimiento a Roberto Alonso, Carlos Madero, Juan Luis Ravé, José Roda, Carlos Rodríguez, Salvador Guzmán, Sira Gadea y Enrique Muñoz por el apoyo brindado en su realización.

2 Juan Agustín Ceán Bermúdez, Diccionario Histórico de los más ilustres profesores de las Bellas Artes en España, (Madrid: Imp. de la Viuda de Ibarra, 1800), t. I, p. 288, y t. IV, p. 62.

3 Purificación Romero García y Ma del Carmen Heredia Moreno, "Noticias sobre el escultor Agustín de Perea", Archivo Hispalense, 171-173, (1973), pp. 273-310; Antonio Torrejón Díaz, El escultor José Montes de Oca, (Sevilla: Diputación Provincial, 1987), p. 41; José Luis Romero Torres, "Agustín de Perea", en De Jerusalén a Sevilla: la Pasión de Jesús, dir. Manuel Lineros Ríos, t. III (Sevilla: Tartessos, 2005), pp. 200201; y José Luis Romero Torres, "Seguidores de Pedro de Mena en Málaga y Antequera", en El triunfo del barroco en la escultura andaluza e hispanoamericana, ed. Lázaro Gila Medina y Francisco Javier Herrera García, (Granada: Universidad de Granada, 2018), p. 146.

4 José L. García, "El sevillano Miguel de Perea talló a la imagen de Jesús Nazareno que se venera en la localidad cordobesa de Baena", Boletín de las Cofradías de Sevilla, 386 (noviembre de 1991), pp. 41-42. 5 José Roda Peña, "Escultura en la Baja Andalucía durante el siglo XVIII: síntesis interpretativa e historiografía reciente", Mirabilia Ars, 1, (2014), p. 172.
} 


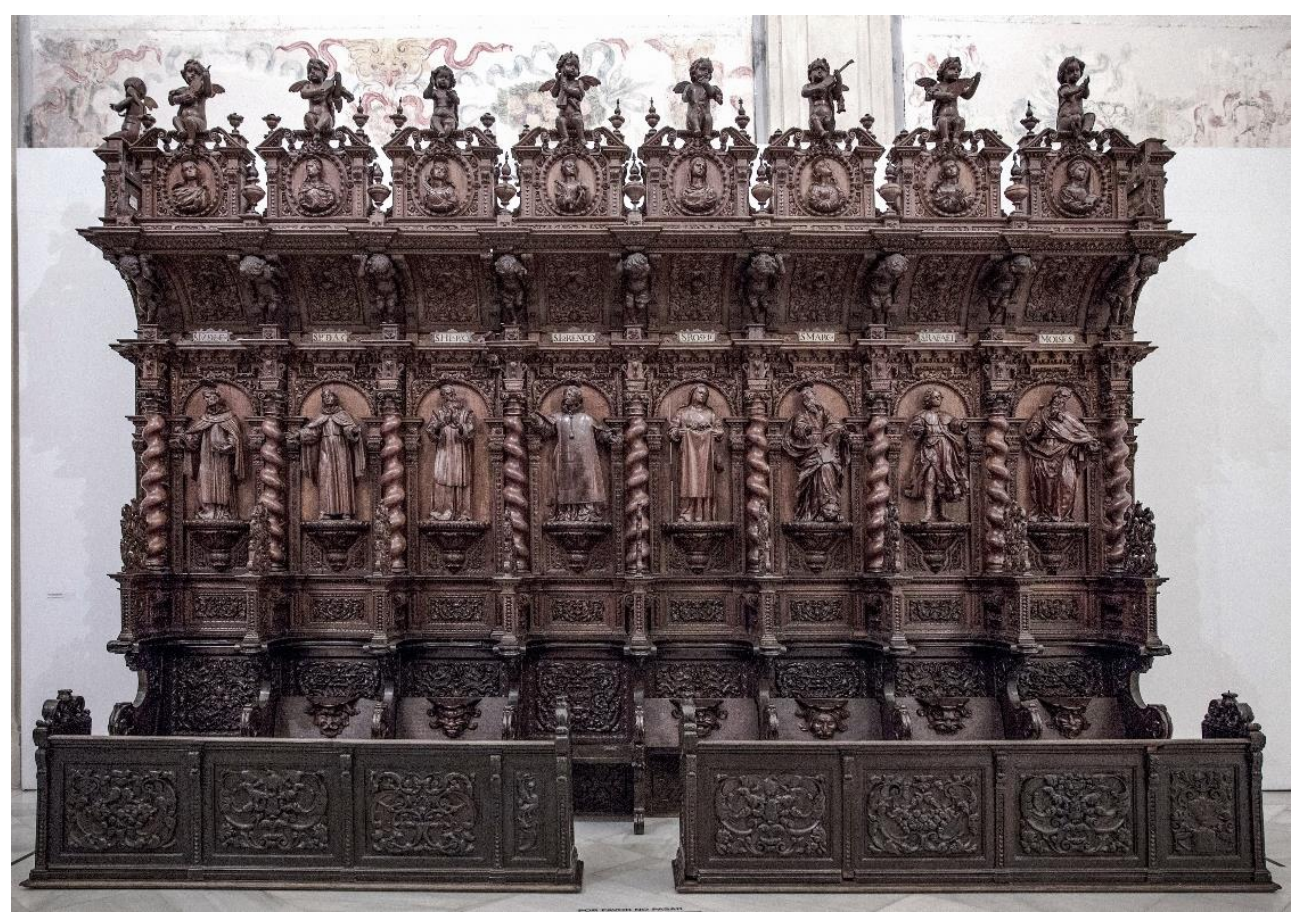

Fig. 1. Juan de Valencia, Agustín y Miguel de Perea, Sillería de coro, 1697-1702, Sevilla, Centro Andaluz de Arte Contemporáneo. OFotografía: autor

\section{Su formación en el taller paterno}

Miguel de Perea nació en Sevilla, en cuya parroquia del Salvador fue bautizado el 5 de marzo de $1680^{6}$. Era el primogénito del escultor malagueño Agustín de Perea Ahumada y de su primera esposa, María de los Reyes, quienes un año antes habían contraído matrimonio en la citada parroquia?. Su padre se había formado en su ciudad natal, ingresando en 1671 como aprendiz del taller de Pedro de Mena (1628-1688), cuando contaba trece años. Por razones no aclaradas, Agustín de Perea abandonó el obrador de Mena antes de lo previsto, trasladando su residencia a Sevilla en torno a $1675^{8}$.

\footnotetext{
${ }^{6}$ Archivo General del Arzobispado de Sevilla, Parroquia del Salvador, Bautismos, L. 23, fol. 226r: "[Miguel Joseph] en martes cinco de marzo de mill seiscientos y ochenta años, yo, don Joan Antonio de Torres $i$ Riuera, cura en esta yglesia collegial de nuestro señor San Saluador de Seuilla baptizè â Miguel Joseph hijo de Miguel [sic] de Perea y de Maria de los Reyes su muger, fue su padrino Bernardo Simon de Pineda, vezino desta collegial aduertile el parentesco espiritual fecho vt supra. Joan Antonio de Torres y Riuera cura [firmado y rubricado]". Cit. en Romero Torres, "Agustín de Perea", p. 201; y Romero Torres, "Seguidores...", p. 146.

7 Romero Torres, "Seguidores...", p. 146.

${ }^{8}$ Así se deduce de su expediente matrimonial, localizado por Romero Torres, "Seguidores...", p. 145.
} 
Como ha subrayado Romero Torres, en la ciudad del Guadalquivir Perea entraría en contacto con el círculo de artistas malagueños, apelando a sus lazos de paisanaje. De este modo, el ensamblador antequerano Bernardo Simón de Pineda (1638-1702) apadrinó a su primogénito -el futuro escultor Miguel de Perea- y en 1681 el dorador malagueño Miguel Parrilla (16311713) haría lo propio con su hija Josefa Rufina. Otro de sus apoyos en la ciudad fue el oficial de ensamblador Juan de Pedrosa, quien lo había acompañado en su traslado de Málaga a Sevilla y le prestaría su testimonio para la formalización de su expediente matrimonial ${ }^{9}$.

El escultor sevillano, de ascendencia antequerana, Pedro Roldán (16241699), también formaba parte de esta comunidad de artistas. Es posible que Agustín de Perea completara su formación en el taller de Roldán, pues Ceán lo incluía entre su nómina de discípulos ${ }^{10}$. Al menos, así parece corroborarlo la presencia de Perea entre los testigos de la boda de una de las hijas del maestro, Francisca Roldán (1650-1712), que se casó el 12 de septiembre de 1677 en la parroquia de San Marcos de Sevilla con el escultor José Felipe Duque Cornejo (1655-1709) ${ }^{11}$. Asimismo, cabe valorar la rápida aclimatación de Agustín de Perea al ambiente estético roldanesco, como prueba su conocido Cristo de la Coronación de la hermandad sevillana del Valle $(1688)^{12}$.

Los primeros años de vida de Miguel de Perea transcurrieron en la calle Sierpes, en la collación del Salvador, donde su padre tenía instalada su residencia y taller. Su infancia se antoja difícil, teniendo en cuenta que quedó huérfano de madre en 1685, con apenas cinco años ${ }^{13}$. Poco tiempo después, en enero del año siguiente, su padre se desposó con María de Bobadilla y Guzmán, hija del pintor Jerónimo de Bobadilla. Este matrimonio sería efímero, pues la contrayente falleció en 1688. Dos años más tarde, Agustín de Perea casaría en terceras nupcias con Marina Victoria de Luque, al parecer hija de un carpintero ${ }^{14}$.

La formación de Miguel de Perea se desarrolló en el taller paterno durante la última década del siglo XVII. Allí se atendían por igual los encargos de imágenes devocionales (así lo acreditan el mencionado Cristo de la Coronación o el San José de la capilla del gremio de carpinteros de lo blanco, de 1694) como los grandes programas escultóricos para retablos. En este sentido, Agustín de Perea mantuvo una relación muy fructífera con el ensamblador Juan de Valencia (ca. 1660-1738) -yerno de Bernardo Simón de Pineda-, con el que llegó a formar una suerte de tándem artístico al

\footnotetext{
${ }^{9}$ Romero Torres, "Seguidores...", p. 146.

${ }^{10}$ Ceán Bermúdez, Diccionario, t. IV, p. 61.

11 La partida original fue destruida en 1936, pero existe copia autorizada en el Archivo Municipal de Córdoba, Expedientes de hidalguía, no 333, s/f.

12 Romero García y Heredia Moreno, "Noticias sobre...", pp. 280-281.

13 Romero Torres, "Seguidores...", pp. 146-147.

14 Romero Torres, "Seguidores...", pp. 147.
} 
convertirse en el escultor que habitualmente suministraba el apartado figurativo de sus retablos ${ }^{15}$.

La obra más ambiciosa que acometieron conjuntamente fue la sillería coral de la cartuja de Nuestra Señora de las Cuevas de Sevilla (1697-1701), que hoy se halla repartida entre la catedral de Cádiz y el Centro Andaluz de Arte Contemporáneo ${ }^{16}$ (Fig. 1). Ceán fue el primero en señalar que Miguel de Perea "ayudó á su padre" en la ejecución de esta sillería ${ }^{17}$, extremo que en principio parecen refrendar las divergencias estilísticas que se aprecian en la talla de los santos de los respaldos ${ }^{18}$. No obstante, discriminar la labor del cada uno resulta una tarea en extremo compleja, puesto que no contamos con ningún referente seguro que permita identificar el estilo juvenil del hijo.

El testamento de Agustín de Perea constituye otra fuente valiosa para conocer algunos otros trabajos epigonales en los que pudo colaborar su hijo. Así, entre las obras que habían quedado pendientes de cobro se citan un San Miguel llevado a Nueva España, una Santa Bárbara realizada para un capellán de coro o las esculturas de dos retablos, ya desaparecidos, que pertenecieron a dos cenobios de la Sierra Norte: la Cartuja y el convento de San Agustín de Cazalla de la Sierra ${ }^{19}$.

\section{El taller de Miguel de Perea y sus trabajos con Juan de Valencia}

Agustín de Perea cayó enfermo en mayo de 1701, falleciendo prematuramente en diciembre del mismo año, con apenas 43 años. Su primogénito quiso perseverar en el oficio, manteniendo abierto el taller familiar en su domicilio de la calle Catalanes. Así lo revela el acuerdo alcanzado con la viuda de su padre, Marina de Luque, quien abandonó la casa para que Miguel de Perea quedara viviendo en ella ${ }^{20}$. Además de heredar la estructura física del taller, es posible que Miguel mantuviera en nómina a alguno de los oficiales o aprendices que habían trabajado junto su padre. De todos ellos solo conocemos el caso del joven Jerónimo de Bobadilla, hijo del pintor homónimo, que en 1699 entró como aprendiz de su padre por tiempo de seis años ${ }^{21}$.

En la escritura de partición de bienes, otorgada en enero de 1702, también se acordó que Miguel de Perea se haría cargo de terminar el retablo de la capilla de Santa Ana en Dos Hermanas (Sevilla), que su padre había concertado de mancomún con Juan de Valencia ${ }^{22}$. Su programa figurativo

\footnotetext{
15 Sobre Valencia, véase Francisco Javier Herrera García, "Algunas consideraciones sobre el arquitecto de retablos Juan de Valencia", Atrio, 3 (1991), pp. 67-80.

16 Romero García y Heredia Moreno, "Noticias...", pp. 281-287.

${ }^{17}$ Ceán Bermúdez, Diccionario, t. IV, p. 62.

18 Romero Torres, "Seguidores...", p. 147.

${ }^{19}$ Romero García y Heredia Moreno, "Noticias...", pp. 274 y 277.

20 Romero García y Heredia Moreno, "Noticias...", p. 307.

${ }^{21}$ Romero García y Heredia Moreno, "Noticias...", p. 276.

22 Romero García y Heredia Moreno, "Noticias...", pp. 307-308; Herrera García, "Algunas consideraciones...", pp. 57-58.
} 


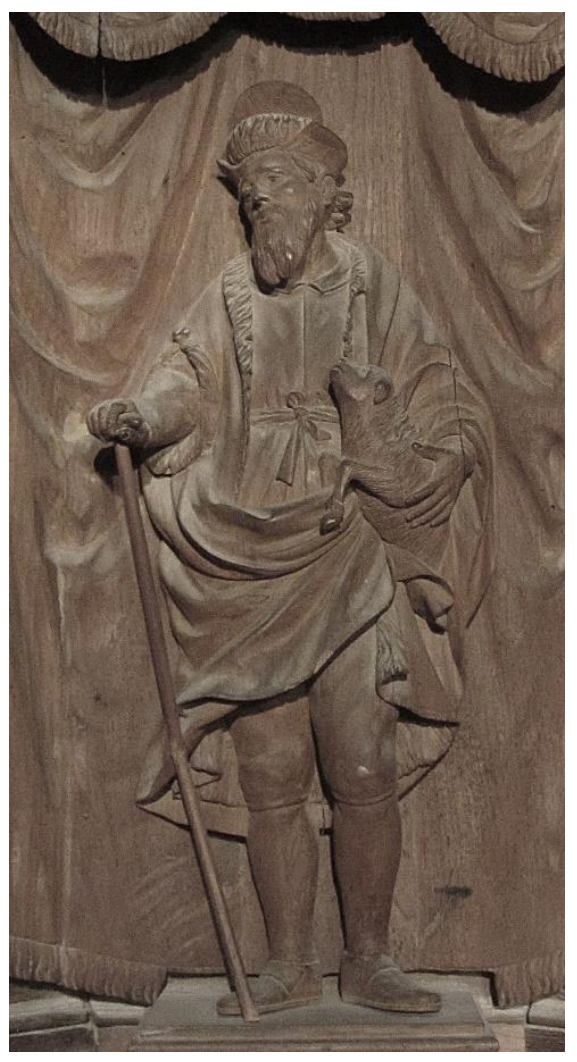

Fig. 2. Miguel de Perea, San Joaquín, 1715-1717, Marchena, parroquia de San Juan Bautista. @Fotografía: Roberto Alonso.

contemplaba la ejecución de dos esculturas de bulto para las calles laterales, representando a San José y San Joaquín, pero no sabemos hasta qué grado intervino el joven Miguel en unas efigies que su padre pudo dejar desbastadas antes de morir ${ }^{23}$.

La compañía artística que Agustín de Perea tenía establecida con Juan de Valencia continuó en la figura de su hijo. Para rubricar esta nueva etapa profesional, el ensamblador convirtió al menor de los Perea en el padrino de su hijo Miguel Antonio José, que fue bautizado el 24 de diciembre de $1702^{24}$. La experiencia de ambos artistas en la sillería de la cartuja de las Cuevas debió allanar el camino para que en 1715 colaboraran de nuevo en la sillería coral de la parroquia de San Juan Bautista de Marchena (Sevilla). Esta obra, de compleja historia constructiva, había sido trazada por el conocido arquitecto de retablos Jerónimo Balbás (1673-1748), quien llegó a tallar dos sillas de muestra ${ }^{25}$. Sin embargo, la ejecución salió a subasta y el contrato se adjudicó finalmente a Valencia, quien se comprometió a realizarla en 60.000

\footnotetext{
${ }^{23}$ La iconografía del retablo se completa con el grupo titular, del siglo XIV, y una escultura de San Roque en el ático, de clara factura manierista.

${ }^{24}$ Herrera García, "Algunas consideraciones...", pp. 57 y 61, nota 11.

25 Juan Luis Ravé Prieto, "Jerónimo de Balbás y la sillería coral de San Juan Bautista de Marchena", Revista de arte sevillano, 2, (1982), pp. 29-33.
} 


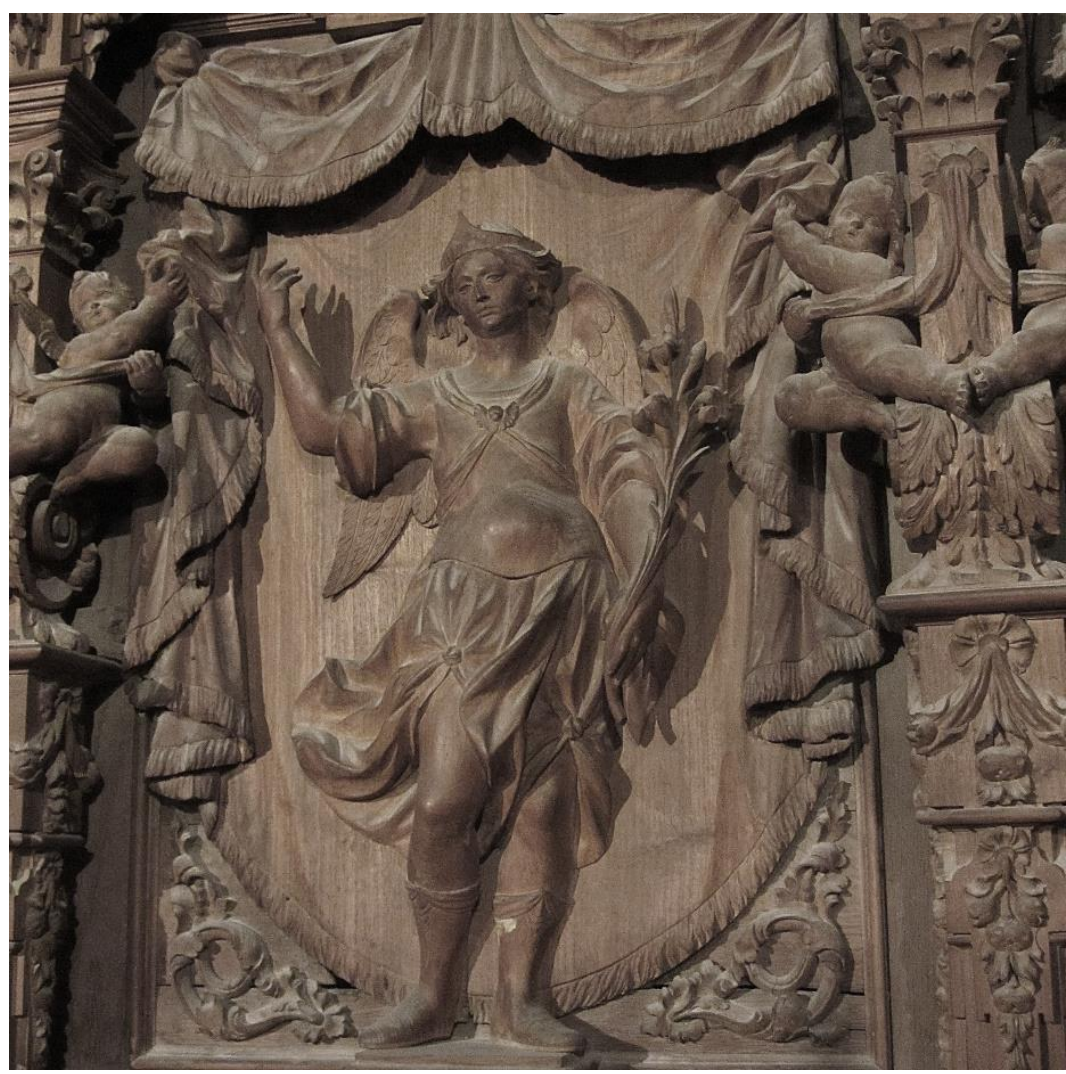

Fig. 3. Miguel de Perea, San Gabriel, 1715-1717, Marchena, parroquia de San Juan Bautista. @Fotografía: Roberto Alonso.

reales $^{26}$. Miguel de Perea actuó como fiador de la escritura de obligación ${ }^{27}$, lo que, con toda lógica, parece indicar que él fue el encargado de suministrar toda la escultura figurativa del conjunto, compuesto por 43 sitiales $^{28}$.

Éste de Marchena debió de ser uno de los encargos más importantes que Perea afrontó en su carrera, a juzgar por el volumen de esculturas requeridas: 29 altorrelieves de santos para los respaldos de las sillas altas, 14 medallones con bustos de santas para las sillas bajas, numerosas hermas o "bichas" para la decoración del guardapolvo y un sinfín de cabezas de querube y ángeles niños, representados en el acto de descubrir unos pabellones textiles. Todas están realizadas en madera de ciprés y, pese a sus lógicas irregularidades, presentan un nivel de calidad sostenido y constituyen un punto de referencia fundamental para profundizar en el estilo y la técnica de Perea. Valoradas en

\footnotetext{
${ }^{26}$ María Salud Caro Quesada, Noticias de escultura (1700-1720), (Sevilla: Guadalquivir, 1992), pp. 230237. La escritura se otorgó el 17 de agosto de 1715. Al hablar de reales, en este trabajo nos referiremos siempre a moneda de vellón.

27 También aparecen como fiadores Fernando de Medina y José García Barrios, dos "hombres conosidos y abonados en esta ciudad".

${ }^{28}$ Francisco Javier Herrera García, El retablo sevillano en la primera mitad del siglo XVIII: evolución y difusión del retablo de estípites, (Sevilla: Diputación Provincial, 2001), p. 353 (aunque por confusión se le denomina Manuel de Perea); y Manuel García Luque, "La impronta de Murillo en la escultura sevillana del siglo XVIII", en Murillo y su estela en Sevilla, dir. Benito Navarrete Prieto, (Sevilla: ICAS-Ayuntamiento de Sevilla, 2017), p. 87.
} 
conjunto, muestran numerosos ecos de la plástica roldanesca e innegables concomitancias expresivas con la obra de su contemporáneo Pedro Duque Cornejo (especialmente evidentes en la efigie de San Joaquín), pero también se advierten matices propios en el gusto por los paños acuchillados y los cabellos limpiamente definidos, que permiten distinguir nítidamente su producción de la del nieto de Roldán (Figs. 2-3).

Aunque Perea y Valencia fueron socios habituales, las circunstancias del encargo no siempre hicieron factible su colaboración. Lo demuestra lo ocurrido un año más tarde, en 1716, cuando Valencia se comprometió a realizar el último cuerpo del retablo mayor del convento hispalense de la Consolación -actualmente en la parroquia de la Concepción de Castilleja de la Cuesta (Sevilla)-, que había dejado inconcluso a su muerte el arquitecto de retablos Cristóbal de Guadix. En este caso, el contrato especifica que la escultura correría a cargo de unos desconocidos Juan Ramírez y Sebastián Varela, tal vez porque Perea se encontraba trabajando a destajo en el elenco escultórico de Marchena y no podía asumir nuevos compromisos profesionales $^{29}$.

En el sentido opuesto, también contamos con ejemplos en los que Miguel de Perea se asoció con otros retablistas. Así, en diciembre de 1718, el escultor se constituyó en fiador del ensamblador Luis de Vilches (ca. 1682-1743) en el contrato del desaparecido retablo mayor de la iglesia de Paymogo (Huelva), lo que sugiere que la imaginería iba correr de su cuenta ${ }^{30}$.

También ha quedado constancia de una colaboración puntual con el maestro de carpintería Juan Tomás Díaz, quien en 1726 se ocupó de tallar el retablo del Santo Cristo en la capilla del colegio de San Telmo de Sevilla. Los comisarios de la obra confiaron a Duque Cornejo la ejecución de los siete ángeles pasionarios que acompañan la escultura del Crucificado, pero quizás por una falta de previsión no se pensó en el relieve que había de decorar la portezuela del sagrario. Este se encomendó a Miguel de Perea, quien representó la imagen alegórica del Cordero eucarístico sobre el libro de los siete sellos (Fig. 4). Se trata de una obra de calidad discreta, en la que no hay que pasar por alto el escaso precio pagado por ella, apenas 75 reales $^{31}$.

En el decenio de 1720, Juan de Valencia y Miguel de Perea volverían a coincidir en la ejecución de un importante conjunto de retablos, lamentablemente desaparecido, realizado para la iglesia del Real Monasterio de Nuestra Señora de la Merced de Sevilla, Casa Grande de los mercedarios calzados. El cenobio se encontraba inmerso en un ambicioso proceso de renovación con la reedificación de su claustro grande por Leonardo de Figueroa y la continuación del programa ornamental de su iglesia, que estrenó portada pétrea, retablos y un ciclo de pintura mural. A comienzos de

\footnotetext{
${ }^{29}$ Caro Quesada, Noticias, pp. 237-238.

30 Caro Quesada, Noticias, pp. 249-250.

31 Mercedes Jos López, La capilla de San Telmo, (Sevilla: Diputación Provincial, 1986), p. 45.
} 


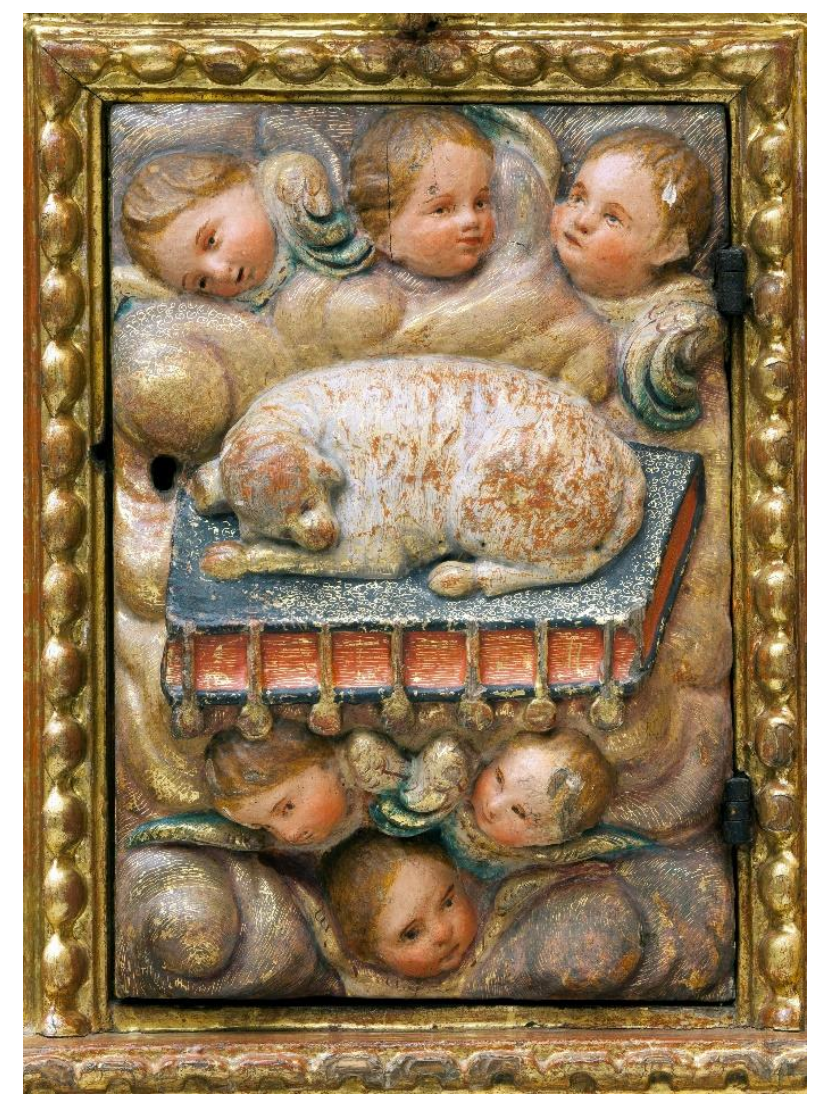

Fig. 4. Miguel de Perea, El cordero eucarístico sobre el libro de los siete sellos, 1726, Sevilla, capilla del palacio de San Telmo. OFotografía: leyendasdesevilla.blogspot.com.

1723, los frailes ya debían haber iniciado las conversaciones con diferentes arquitectos de retablos, pues en marzo el Padre General recibió una carta del cartujo fray Luis José de Urebal, recomendándole para este propósito al artífice giennense Antonio Primo (1708-1753) ${ }^{32}$. El encargo recaería finalmente en el equipo formado por Valencia y Perea, quienes suscribieron escritura de obligación el 30 de agosto de aquel año. Curiosamente, en esta ocasión el contratante fue el escultor, actuando Valencia como fiador. Ambos se comprometieron a realizar dos retablos colaterales para el crucero de la iglesia y dos más para los pilares del arco toral, todos ellos en madera de pino, en precio de 43.000 reales $^{33}$. La parte arquitectónica debió finalizarse en los dos años estipulados en la escritura, pues en julio de 1725 los mercedarios la cancelaron en lo tocante a Juan de Valencia ${ }^{34}$. Aunque Perea se retrasara en su compromiso, es seguro que acabaría entregando el apartado figurativo, pues una memoria de las pinturas y esculturas más

\footnotetext{
32 José Gestoso y Pérez, Ensayo de un diccionario de los artífices que florecieron en esta ciudad de Sevilla desde el siglo XIII hasta el XVIII inclusive, t. I (Sevilla: La Andalucía Moderna, 1899), p. 200.

${ }^{33}$ Archivo Histórico Provincial de Sevilla (AHPSe), Protocolos Notariales de Sevilla (PNSe), Oficio 4, 1723, Leg. 2838, fol. 621r-v. Lo publicó Heliodoro Sancho Corbacho, Arquitectura sevillana del siglo XVIII, (Sevilla: Universidad de Sevilla, 1934), p. 67.

${ }^{34}$ AHPSe, PNSe, Oficio 4, 1725, Leg. 2840, fol. 560r-v.
} 
notables del convento, redactada poco tiempo después, confirmaba que "toda la escultura de la Capilla mayor en sus colaterales es [de] Miguel de Perea"35. De hecho, la entrega definitiva tuvo que producirse antes de 1727, cuando Domingo Martínez (1688-1749) y Miguel Delgado Moreno firmaron el contrato para ejecutar las pinturas murales de la capilla mayor y el crucero, así como el dorado y policromía de estos retablos ${ }^{36}$.

Durante el proceso constructivo de los retablos de la Merced, Perea recibió un encargo de otra comunidad monástica de Sevilla, la del convento de religiosas agustinas de San Leandro. Una de sus profesas, doña Juana de la Parra y Puerto, había resultado beneficiada en un pleito que se había desatado a propósito de los mayorazgos de sus padres, lo que en 1723 le llevó a solicitar licencia al visitador para poder emplear sus rentas en la institución de una serie de misas en la octava del Corpus, la compra de un frontal de altar y "generalmente para todos los gastos de las nessesidades religiosas". Parece que la comunidad determinó necesario invertir este dinero en la ejecución de un cancel para la iglesia, obra que la religiosa concertó con Miguel de Perea el 8 de abril de $1724^{37}$ (Fig. 5). La escritura especificaba que esta estructura de talla debía realizarse en una combinación de maderas (pino para el armazón, caoba para los tableros, y naranjo para los embutidos), reservando el vidrio para los cuatro vanos que procurarían algo de luz natural al templo. No sabemos si el plazo de diez meses o los 12.000 reales previstos en el contrato resultaron insuficientes para acometer una obra de esta envergadura, pero lo cierto es que Perea incumplió su compromiso. La reacción no se hizo esperar y las religiosas interpusieron un pleito ante la Real Audiencia, probablemente en junio de 1725, a juzgar por un poder a procuradores que entonces otorgó Perea ${ }^{38}$. La pérdida del expediente judicial nos impide conocer los términos en que se desarrolló el litigio, aunque sabemos que Perea sería condenado al pago de 4.000 reales -como él mismo confesaría en su testamento- lo que desencadenó el embargo de sus bienes.

Por el momento, resulta muy difícil determinar si Perea acabó rematando la obra o la comunidad tuvo que recurrir a un segundo artífice ${ }^{39}$. Lo cierto es que el cancel acabaría instalándose en 1729 -según reza la inscripción que recorre su cornisa, donde también se recuerda el nombre de la donante ${ }^{40}$ - y que su morfología concuerda con los términos fijados en el contrato. El mueble destaca por su fina labra y su atractivo diseño, que alterna los clásicos motivos geométricos con la jugosa talla de hojas de cardo, festones y follajes,

\footnotetext{
35 Fernando Quiles García e Ignacio Cano Rivero, Bernardo Lorente Germán y la pintura sevillana de su tiempo (1680-1759), (Madrid: Fernando Villaverde Ediciones, 2006), p. 300. La memoria está fechada en 1732.

${ }^{36}$ Quiles García y Cano Rivero, Bernardo Lorente Germán, pp. 280-281.

37 AHPSE, Celomar, Leg. 23834, pieza 56, fols. 176r-180v.

${ }^{38}$ AHPSe, Oficio 13, 1725, Leg. 8196, fol. 309r-v.

39 El fiador del contrato fue un tal Alonso Benítez, vecino de San Andrés, pero como no se especificó su oficio entendemos que no pertenecía al gremio.

${ }^{40}$ Andrés Llordén, Convento de San Leandro de Sevilla (notas y documentos para su historia), (Málaga, 1973), p. 70.
} 


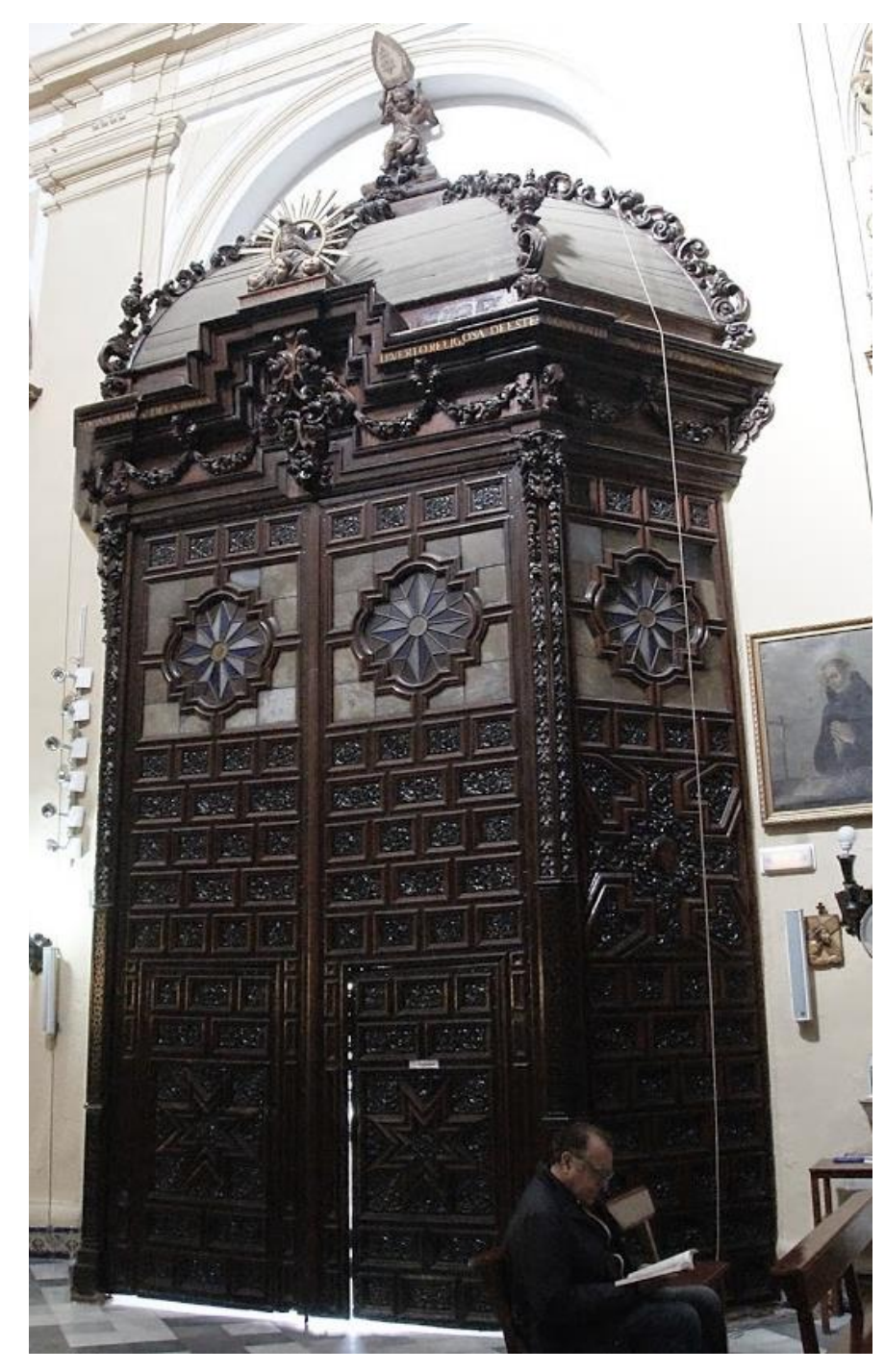

Fig. 5. Miguel de Perea (?), Cancel, 1724-1729, Sevilla, iglesia del monasterio de San Leandro. OFotografía: autor

habituales en el repertorio ornamental sevillano del momento. Sobre la cornisa aparece un Cordero eucarístico sobre un trono de nubes y querubes y en la cúspide un Ángel niño jugueteando con una mitra. Ninguna de estas esculturas policromadas aparece expresamente mencionada en el contrato, pero es posible que se añadieran en el transcurso de la obra, aludiendo, respectivamente, al fervor eucarístico de la donante y a la dignidad episcopal del santo titular del convento.

\section{La familia de Miguel de Perea. Aspectos socioeconómicos}

En la primavera de 1702, cuando apenas habían transcurrido unos meses desde la muerte de su padre, Miguel de Perea contrajo matrimonio con Ana Castellar de Isea, hija de Juan Antonio Castellar de Isea, escribano de provincia de la Real Audiencia, y de doña Leandra María Gómez de 
Valbuena ${ }^{41}$. La escritura de dote, que incluía vestuario, joyas y menaje del hogar (como "dos escudillas de China", seguramente realizadas en porcelana), se otorgó el 25 de mayo, ascendiendo su monto a 7.926 reales $^{42}$.

En algún momento aún por determinar, el matrimonio trasladó su residencia a la collación de la Magdalena, donde a partir de 1709 se les documenta domiciliados de forma permanente en la calle Cantarranas (actual Gravina $)^{43}$. No obstante, ya debían ser feligreses de esta parroquia desde al menos 1705, cuando recibió las aguas del bautismo su hijo Salvador Leonardo ${ }^{44}$. Le seguirían otros nueve hijos del matrimonio: Juan Manuel José $(1709)^{45}$, Ana Petronila Salvadora $(1711)^{46}$, Josefa Nicolasa Salvadora $(1712)^{47}$, Antonia Victoria Salvadora $(1714)^{48}$, Ana Salvadora (1716) ${ }^{49}$, Bernabé Vicente Salvador $(1718)^{50}$, Petronila María Salvadora Anastasia $(1721)^{51}$, Salvador Pedro María $(1725)^{52}$ y Juan Domingo Salvador $(1726)^{53}$. Siguiendo una costumbre habitual en la época, Perea aprovechó el ritual del bautismo para sellar su amistad con alguno de sus más estrechos colaboradores. De este modo, convirtió a Juan de Valencia en padrino de su hija Josefa Nicolasa, y al conocido pintor Domingo Martínez en padrino de su hija Petronila.

Tan abundante prole apuntaría, en principio, a una cierta prosperidad económica, pero las cifras solo esconden una tragedia humana, ya que solo cuatro de los hijos sobrevivían a finales de 1726. En aquel momento el mayor, Salvador, ya se había ordenado como clérigo de menores órdenes, mientras que Josefa, Petronila y el recién nacido Juan Domingo permanecían en minoría de edad. Este extremo lo conocemos gracias al testimonio de Ana Castellar, quien, al no lograr recuperarse del parto de su último hijo, ordenó su testamento el 30 de diciembre ${ }^{54}$, siendo enterrada al día siguiente en la parroquia de la Magdalena55.

Algunos meses después, en abril de 1727, Miguel de Perea, como albacea testamentario dispuso el inventario de los bienes de su casa y taller, pues

\footnotetext{
${ }^{41}$ Los nombres de sus progenitores están extraídos del testamento (véase nota 54).

42 AHPSe, PNSe, Oficio 21, 1702, Leg. 14641, fol. 709r-711v. El documento está muy deteriorado por la acción de los xilófagos y la humedad.

${ }^{43}$ Archivo Parroquial de Santa María Magdalena de Sevilla (APSMSe), Padrón $1^{\circ}$ de 1709, C/ Cantarranas, no 69. Junto al matrimonio vive el hermano de ella, Juan Manuel Castellar, y dos desconocidas llamadas Rufina María y María Leandra Gómez.

${ }^{44}$ APSMSe, Bautismos, L. 26, fol. 92r. Apadrinado por Leonardo José de Castro.

45 APSMSe, Bautismos, L. 26, fol. 187v. Apadrinado por Juan Benítez.

46 APSMSe, Bautismos, L. 26, fol. 234v. Apadrinada por José del Águila.

47 APSMSe, Bautismos, L. 26, fol. 266r. Apadrinada por el ensamblador Juan de Valencia.

${ }^{48}$ APSMSe, Bautismos, L. 26, fol. 327v. Apadrinada por Agustín Rivero.

${ }^{49}$ APSMSe, Bautismos, L. 27, fol. 44r. Apadrinada por Manuel de Castro.

50 APSMSe, Bautismos, L. 27, fol. 77v. Apadrinado por su hermano Salvador de Perea.

${ }^{51}$ APSMSe, Bautismos, L. 27, fol. 163v. Apadrinada por el pintor Domingo Martínez.

52 APSMSe, Bautismos, L. 27, fol. 277v. Apadrinado por José Castellar.

${ }^{53}$ APSMSe, Bautismos, L. 27, fol. 318r. Apadrinado por José Castellar.

54 AHPSe, PNSe, Oficio 13, 1726, Leg. 8197, fol. 598r-v. Declaraba ser hija legítima de Juan Antonio Castellar de Isea, escribano de provincia de la Real Audiencia, y de doña Leandra María Gómez de Valbuena, ambos difuntos. Dejó a voluntad de sus albaceas la imposición de misas y dio 8 maravedís de limosna a las mandas acostumbradas. Nombró por albaceas a su marido y a su hermano Juan Manuel Castellar, y como herederos a sus cuatro hijos y a su marido.

${ }^{55}$ APSMSe, Defunciones, L. 5, fol. 89r.
} 
todos tuvieron la consideración de gananciales. De este modo, el inventario nos ofrece una inusual radiografía del estilo de vida que podía mantener un mediano escultor sevillano del XVIII. Entre los bienes más preciados de su ajuar doméstico se encontraban la "cama de colgar de tres varandillas, madera galeada", dos bufetes ingleses de estrado, dos escritorios, dos bufetillos y una papelera, todos ellos realizados en materias nobles como la caoba y ébano con enchapaduras de marfil. La madera de pino quedaría relegada para muebles de uso corriente, como la cuna ${ }^{56}$.

Por lo que respecta a pinturas y esculturas, el inventario no proporciona ningún tipo de autoría, limitándose a señalar las dimensiones de las piezas y su iconografía, lo que al menos nos permite acercarnos a la intimidad de sus devociones domésticas. El matrimonio contaba con dos tallas de pequeño formato de Nuestra Señora del Rosario y un Crucificado, y con lienzos de la Santísima Trinidad, Nuestra Señora de la Soledad, la Sagrada Familia en su Huida a Egipto y Nuestra Señora de la Concepción "en papel" (aludiendo seguramente a una estampa enmarcada). Los habituales países y otros lienzos de "diferentes deuosiones" componían el resto de la colección, hasta sumar veinticinco pinturas.

La existencia desahogada de los Perea también se advierte en la posesión de algunos objetos de platería -como la cubertería, las cajas para el tabaco o dos relicarios grandes-, algunas joyas de la viuda -donde figuran pendientes de perlas, cruces de esmeraldas y diamantes- $y$, por supuesto, en el vestuario, conformado por sombreros de tres picos, sayas, monillos, guardapiés, capotes, casacas, chupas... Siguiendo la moda dieciochesca, las prendas femeninas refulgían en colores violáceos, celestes y melados, aunque el atuendo de Miguel de Perea se distinguía por su mayor sobriedad cromática ${ }^{57}$.

En el inventario también quedó recogido el instrumental del taller, que nos da una ligera idea sobre la entidad que pudo tener este espacio creativo. Allí se podían encontrar cuatro bancos de carpintero (lo que, en principio, permitiría el trabajo simultáneo de un maestro y tres oficiales), así como tres sierras, dos prensas, unos "garauatos de fierro" $y$, en fin, "quarenta piesas de todo genero de herramientas del exersisio de escultor".

\section{El testamento de $\mathbf{1 7 2 8}$ y sus últimos años en Sevilla}

En el verano de 1728 fue Miguel de Perea quien, hallándose enfermo, decidió ordenar sus últimas voluntades a través de un primer testamento fechado a 12 de agosto ${ }^{58}$. Se trata de un documento sustancioso como pocos, que nos informa, en primer lugar, de que en aquel momento aún vivían los

\footnotetext{
${ }^{56}$ AHPSE, Oficio 13, 1727, Leg. 8198, fol. 269r-270v.

57 Es el caso del "vestido de hombre de paño negro de Yngalatarra [sic] nueuo, que se conpone de casaca y calzones".

${ }^{58}$ AHPSe, PNSe, Oficio 13, 1728, Leg. 8198, fols. 313r-314v.
} 
cuatro hijos anteriormente citados, añadiéndose ahora que el mayor, Salvador, había trasladado su residencia a Roma. Previendo su inminente muerte, Perea dejaba a los menores bajo la tutela de su compadre José del Águila, a quien también nombraba albacea testamentario junto a su cuñado José Castellar. Asimismo, declaraba hallarse pobre por tener los bienes de casa embargados por los monasterios de San Leandro y San Pablo. Ya hemos visto cómo la comunidad agustina había solicitado la incautación de sus bienes por el asunto del cancel, mientras que en el caso de los dominicos la causa pudo deberse al impago de la renta de la casa que le tenían alquilada desde hacía tres años.

Más allá de proporcionarnos estas noticias biográficas, el testamento se revela como una fuente fundamental para profundizar en la producción artística de Perea, ya que el escultor se refiere en primera persona a una serie de obras que había realizado o estaba ultimando. En primer lugar, declaraba haber concertado en diciembre de 1727 un retablo para la Virgen del Mayor Dolor que se veneraba en la capilla mayor de la ermita de San Sebastián del Cerro de Andévalo (Huelva). Perea ajustó esta máquina lignaria en 10.500 reales, a realizar en el término de dos años, "quedando de mi cargo la talla, ensamblaje y escultura"59. Aunque el retablo fue destruido en la Guerra Civil, por una estampa de Nicolás Carrasco, datada en 1743, conocemos que se trataba de un sencillo retablo-hornacina, carente de soporte alguno. Su apartado escultórico se limitaba a una pareja de ángeles niños que sostenían un medallón con el tema de la Quinta Angustia en la cúspide, otra que descorría un pabellón textil, buscando el consabido efecto escenográfico, y algunas cabezas de querube que aparecían repartidas por la peana y el marco de la hornacina ${ }^{60}$.

La proyección retablística de Miguel de Perea en la provincia de Huelva también viene avalada por un "adorno de talla" que ya tenía terminado para la hermandad de San Sebastián de la villa de Aroche. Había ajustado su hechura con el mayordomo y regidor perpetuo Sebastián Parreño, en precio de 60 pesos escudos, a los que había que añadir 5 más ofrecidos por el mayordomo de la hermandad de Nuestra Señora de la Aurora de aquel municipio.

Por lo que respecta a su faceta como escultor, en aquel momento Perea se encontraba tallando dos Ángeles lampareros para el convento de San Francisco de Carmona (Sevilla). Los había ajustado con fray Juan Lasso en 900 reales, de los que ya había recibido 300 a cuenta. El comitente ha de identificarse con fray Juan Lasso de la Vega y Cansino (1674-1752), franciscano natural de Carmona que entonces residía en Sevilla, en la Casa

\footnotetext{
${ }^{59}$ Había concertado la obra con el presbítero Sebastián Benito Otaldón. Declaraba haber recibido ya 3.317 reales y haber conducido a la ermita la tercera parte de la obra, aunque ya tenía acabada más de la mitad. ${ }^{60}$ El grabado, de colección particular, presenta una cartela en la parte inferior que señala su condición de "verdadero retrato" y la concesión de 40 días de indulgencia por los obispos de Icossio y Gadara, auxiliares de la mitra hispalense.
} 
Grande de San Francisco. Años más tarde pasaría a Indias como obispo de Santiago de Cuba, aunque interesa resaltar su labor pastoral como comisario visitador de la Venerable Orden Tercera ${ }^{61}$. Es posible que Perea formara parte de esta congregación de seglares, pues se refiere a fray Juan Lasso como "custodio actual de mi religion de mi padre señor San Francisco".

El testamento también confirma algunos trabajos menores para el Colegio jesuita de la Encarnación de Marchena, por encargo del padre Lorenzo de Carmona. Perea se refiere expresamente a tres esculturas de San Francisco de Borja, San Estanislao de Kostka y San Luis Gonzaga que ya tenía acabadas en madera, a falta del encarnado "que entro en dicho âjustte". La crónica del colegio aclara que las imágenes iban a ser destinadas a un retablo dedicado a San Francisco de Borja, que se colocaría en 1732 a devoción del padre Lorenzo de Carmona62. Tras la expulsión de la Compañía, el mueble fue llevado a la iglesia de Santa María de la Mota de la misma localidad ${ }^{63}$, donde aún se conserva la imagen de vestir del santo titular. Se trata de una obra algo dura en la resolución de sus facciones, claramente inspiradas en la imagen del santo duque de Gandía que un siglo antes tallara Montañés para la Profesa hispalense. Se desconoce el paradero de los otros dos santos, que a juzgar por el precio de su ajuste podían ser obras de talla completa y tamaño académico ${ }^{64}$.

Perea también tenía acabadas en blanco unas tallas de San Ignacio, San Francisco de Asís y la Inmaculada Concepción, ajustadas en 24 pesos escudos con el mercader Juan Viñado, vecino de Marchena ${ }^{65}$. Teniendo en cuenta su bajo precio -que incluía su encarnado- debían ser obras de candelero, tal vez destinadas para la devoción doméstica o para un pequeño retablo de oratorio.

Junto a estos trabajos en curso, el testamento documenta otros ya terminados que aún estaban pendientes de cobro, en algún caso por desavenencias surgidas con el cliente. Es lo que ocurrió con Antonio Montenegro, quien le encargó un retablo para la sacristía del convento de San Francisco Casa Grande de Sevilla. Tras el abono de su importe, Montenegro encomendó a Perea la hechura de una imagen de San José y la de otros dos santos no identificados, "las que no se ajustaron por auerme dicho que despues de âcauadas me satisfaria lo que yo dijese [...] y despues no me las quiso pagar, diziendo que por el retablo le auia lleuado mucho y que con la demasia me hiziese pago". No sabemos si Perea llegaría a cobrar los 300 reales que reclamaba por estas obras, como tampoco los 140 reales que le

\footnotetext{
${ }^{61}$ Salvador Rodríguez Becerra, "El franciscano Juan Lasso de la Vega, obispo de Cuba, en Aportaciones al Diccionario Biográfico Franciscano de España, Portugal, Iberoamérica y Filipinas, (Córdoba: Asociación Hispánica de Estudios Franciscanos, 2014), p. 238.

62 Julián Navarro Lozano, La Compañía de Jesús en el estado de los Duques de Arcos. El Colegio de Marchena (siglos XVI-XVIII), (Granada: Universidad, 2002).

63 Juan Luis Ravé Prieto, Arte religioso en Marchena, siglos XV al XIX, (Sevilla: Junta de Andalucía, 1986), p. 87.

${ }^{64}$ San Francisco de Borja se ajustó en tan solo 8 pesos escudos y los otros en 50 , lo que equivale a más del triple (25 la unidad).

65 Declaraba haber cobrado ya 8 pesos, en dos recibos de 6 y 2.
} 
debía el presbítero Antonio de Morales, vecino de "La Palma" (población que ha de identificarse con La Palma del Condado, en Huelva) ${ }^{66}$, por el resto de unas imágenes que le había realizado hacía más de cuatro años. Aunque la fuente no lo especifica, es posible que en la formalización del encargo hubiera mediado un desconocido Miguel López, asimismo vecino de La Palma, al que Perea perdonaba algunas deudas "en reconpensa de âlgunas ôbras que por su ynterposizion ê hecho". En su nómina de deudores también figura el ensamblador Francisco de Estrada, a quien el escultor había comprado un pequeño tabernáculo que dejó en su taller para que hiciera unos arreglos y aún no le había sido devuelto ${ }^{67}$, e incluso un miembro del estado eclesiástico, Andrés de las Piedras, clérigo conyugal de la sacristía del Sagrario, a quien Perea había prestado 100 reales.

La relación de acreedores también ofrece una valiosa información para profundizar en el funcionamiento de los talleres de escultura en aquella época. Así, el escultor confesaba ser deudor de dos tratantes de madera, Francisco de Medina y Juan de Murias, quienes le habían fiado material, así como de Nicolás de Escobar, mercader de lienzos, "de resto de mercancias que e sacado de su casa". Más interesante aún resulta la deuda de 150 reales que el escultor había contraído con su "compadre" el pintor Domingo Martínez, por "diferentes cosas que me â pintado". Lo más probable es que se tratara de trabajos de policromía, pues, como hemos visto, Perea tenía por costumbre cerrar con los clientes el precio de las esculturas ya policromadas, aunque esta labor la subcontrataba con pintores y doradores de su confianza. Esta práctica debió aprenderla en el taller paterno, pues sabemos que dos imágenes de la Virgen del Rosario y San José, de vara de alto, que se encontraban en blanco cuando Agustín de Perea falleció, fueron llevadas al taller del estofador José López para que las policromara antes de ser entregadas al cliente ${ }^{68}$.

Por último, merece destacarse que entre los testigos del testamento de Miguel de Perea aparece un oficial de escultura Ilamado "Benito del Castillo". Como ya advirtió Antonio Torrejón, este no es otro que el escultor Benito de Hita y Castillo69. En aquel momento, más que un oficial debía ser un aprendiz, como revela su corta edad (apenas catorce años) y el hecho de que estuviera viviendo en casa del maestro, según acredita el padrón parroquial de $1729^{70}$. Este periodo de aprendizaje no se prolongaría más allá de 1730 , cuando se constata la ausencia del muchacho en el domicilio de Perea ${ }^{71}$.

\footnotetext{
${ }^{66}$ Aunque bien pudiera tratarse de la isla canaria, el hecho de que el testador no concrete este extremo invita a identificarla con la vecina localidad onubense.

67 Los arreglos consistían en unos adornos de talla. Además de los 200 reales que había pagado por el tabernáculo, el ensamblador le debía otros 200 que había abonado en su nombre al mercader de lienzos Nicolás de Escobar.

68 Romero García y Heredia Moreno, "Noticias...", p. 307.

69 Torrejón Díaz, El escultor, p. 41. También recoge la noticia Carmen García Rosell, "Benito de Hita y Castillo", en De Jerusalén a Sevilla: la Pasión de Jesús, dir. Manel Lineros Ríos, t. IV, (Sevilla: Tartessos, 2005), p. 250.

70 García Luque, "La impronta...", p. 87, nota 24.

${ }^{71}$ APSMSe, Padrón $1^{\circ}$ de 1729, Callejuela del Santísimo Sacramento, casa no 139.
} 
Tal vez no sea casual que la salida del aprendiz coincidiera con la mudanza de Miguel de Perea, que en el padrón de 1730 ya figura viviendo en la calle del Santísimo Sacramento, en la misma collación de la Magdalena. Es posible que los dominicos lo desahuciaran de las casas de la calle Cantarranas, ya fuera por el impago de su renta o por las dificultades que entonces atravesaba el mercado inmobiliario en la ciudad, necesitado con urgencia de viviendas libres para acoger el creciente número de foráneos que habían acudido a Sevilla atraídos por la presencia de Felipe $\mathrm{V}$ en la ciudad, durante el Ilamado "Lustro Real" (1729-1733).

En esta coyuntura, la tragedia volvió a golpear la vida de Miguel de Perea, que el 2 de febrero de 1730 enterraba a su hija Josefa en la parroquia de la Magdalena, tras morir siendo doncella ${ }^{72}$. Por aquel tiempo también perdió a su hijo pequeño, Juan Manuel, que no aparece citado en el segundo testamento que otorgó el escultor el 29 de mayo de ese mismo año. En este documento, de extensión mucho más reducida, Perea señaló que había gastado 400 pesos para costear el viaje y la estancia romana de su hijo el clérigo Salvador, quien aún permanecía en la capital pontificia. Asimismo, sustituyó como albacea y curador de su hija Petronila a José del Águila -tal vez por fallecimiento de este último-, nombrando en su lugar a un desconocido Juan de Peñarrieta ${ }^{73}$.

\section{La década de 1730: de Castro del Río a Granada}

Miguel de Perea, que reconocía gozar de buena salud en su testamento de 1730, podía estar barajando su marcha de la ciudad cuando otorgó este instrumento notarial, pues significativamente esta es la última noticia que poseemos del escultor en Sevilla, desapareciendo su rastro del padrón parroquial de la Magdalena en 1731.

Es probable que en aquel verano Perea pusiera rumbo a la villa cordobesa de Castro del Río, tal vez para trabajar en el retablo mayor del Hospital de Jesús Nazareno, que había contratado en 1729 el maestro sevillano Gaspar Lorenzo de los Cobos, o más probablemente en el desaparecido retablo del convento dominico de Scala Coeli, cuya ensambladura también se ha atribuido a De los $\operatorname{Cobos}^{74}$. Esta hipótesis daría sustento al enigmático documento que en 1991 encontró Miguel Ángel Pérez durante la restauración de la imagen de Jesús Nazareno de Baena. Se trata de un manuscrito que lamentablemente ha llegado incompleto, en el que no obstante pudo leerse: "Re[inando... F] eliph V año/ de [...] D. ${ }^{n}$ Mig[ue]l de/ Pe[rea estan]do a la sason

\footnotetext{
72 APSMSe, Defunciones, L. 5, fol. 135r.

73 AHPSe, PNSe, Oficio 13, 1730, Leg. 8199, fol. 248r-v.

74 María Ángeles Raya Raya, "Gaspar Lorenzo de los Cobos", en Diccionario Biográfico Español, (Madrid: Real Academia de la Historia, 2009-2013), ad vocem.
} 


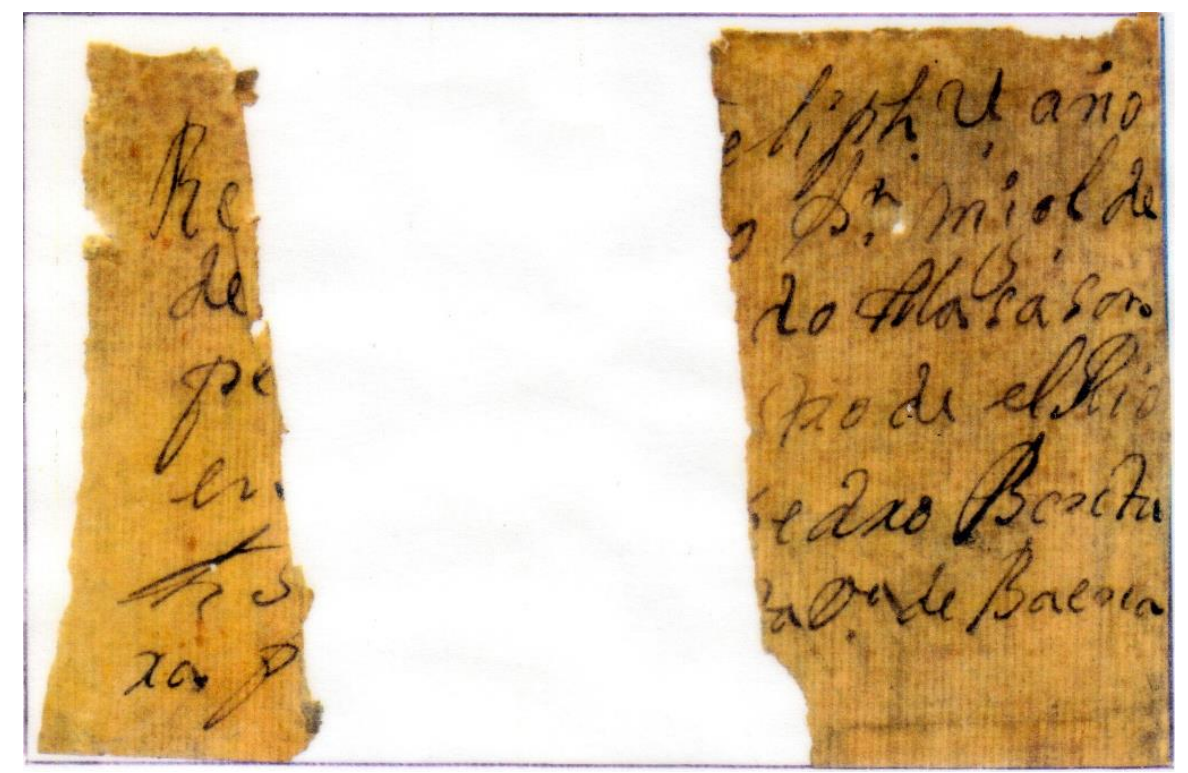

Fig. 6. Documento hallado en el interior de la imagen de Jesús Nazareno de Baena. CFotografía: Archivo cofradía de Jesús Nazareno de Baena.

/en [... Cas]tro de el Rio/ his [... P] edro Bentu/ra p[... I]a v. a de Baena"75 (Fig. $6)$.

El hallazgo vino a poner sobre el mapa la enigmática figura de Miguel de Perea y desveló el nombre del comitente, Pedro de San Buenaventura, que fue párroco de la iglesia de San Pedro de Baena. Aunque la laguna documental impidió precisar la datación de la imagen, más allá del amplio rango cronológico que abarca el reinado de Felipe $V$, el cerco pudo estrecharse con el hallazgo del testamento del sacerdote. En este documento notarial, fechado en enero de 1733, Pedro de San Buenaventura declaraba haber costeado "una Ymagen de Jesús Nazareno que de presente tengo en estas mis casas", ordenando que, tras su fallecimiento y el de su sobrina, la escultura fuera trasladada a una capilla funeraria fundada por sus abuelos en el convento de San Francisco de Baena ${ }^{76}$. A tenor de lo expuesto, lo más probable es que Perea esculpiera el Nazareno de Baena entre 1730 y 1732.

Por su gran arraigo devocional, son múltiples las intervenciones que se han sucedido sobre la imagen a lo largo del tiempo. Restan como originales la cabeza, manos y pies, realizados en madera de pino, pero no así el candelero,

\footnotetext{
75 García, "El sevillano...". El manuscrito únicamente es conocido por fotografía, aunque al parecer fue introducido en el nuevo candelero que realizó Miguel Ángel Pérez en 1991.

76 Juan Aranda Doncel, "La Orden Seráfica en tierras cordobesas durante el siglo XVIII: el convento de San Francisco de Baena", Ituci, 5, (2015), p. 87.
} 
que fue sustituido por última vez en $1991^{77}$. La valoración volumétrica de la cabeza muestra una inquietante cercanía con los modelos estéticos de Duque Cornejo, como se advierte en el tratamiento compacto y sinuoso del cabello, el arabesco que dibuja el bigote o la genuina nariz aguileña (Figs. 7-8). Tratándose de una imagen dieciochesca también resulta llamativa la ausencia de ojos de cristal, lo que corroboraría la hipótesis de que Miguel de Perea solo se encontraba en Castro del Río de forma temporal, seguramente trabajando en el programa figurativo de un retablo, cuyas imágenes no precisan este tipo de aditamentos vítreos.

Si Miguel de Perea regresó a Sevilla después de su estancia en Castro del Río es un interrogante al que por el momento no podemos dar respuesta. Sin embargo, todo apunta a que durante la década de 1730 el escultor trató de abrirse camino fuera de su ciudad natal. Más allá de sus motivaciones personales, resulta pertinente ponderar el estado en que se encontraba el mercado escultórico sevillano en aquel tiempo. La presencia de la Corte en la ciudad había incentivado la ya de por sí intensa actividad constructiva que venían promoviendo diferentes instituciones civiles y religiosas, generando una indudable demanda de obra artística para alhajar los nuevos espacios que se estaban creando o adecentando. Sin embargo, los grandes encargos patrocinados por la mitra, la catedral o la Compañía de Jesús, e incluso otros más modestos promovidos por las hermandades, estaban siendo monopolizados por el taller de Pedro Duque Cornejo, quien para 1730 había logrado imponer su hegemonía en el panorama escultórico sevillano.

Miguel de Perea parece que quedó al margen de este importante movimiento artístico desarrollado durante los años del Lustro Real, y su presencia ni siquiera se rastrea en la obra de la portada del Colegio de Mareantes de San Telmo, donde participaron la mayoría de los escultores que entonces se encontraban activos en la ciudad: Duque Cornejo, Bartolomé y Manuel García de Santiago, Domenico Grasselli, Pedro Castillejo e incluso el propio discípulo de Perea, Benito de Hita y Castillo ${ }^{78}$. En este contexto, no resulta extraño que nuestro escultor buscara explorar nuevos horizontes profesionales en alguna otra ciudad donde el mercado escultórico estuviera más descongestionado, iniciando un camino que más tarde emprenderían el portugués Cayetano de Acosta (1709-1778) y el veneciano Domenico Grasselli, quienes pusieron rumbo a Cádiz a finales de los años treinta ${ }^{79}$.

Como recientemente ha descubierto Roda, el nuevo destino de Miguel de Perea sería la ciudad de Granada ${ }^{80}$. En 1735 vivía en la calle del Águila de esta ciudad un "Miguel de Perea" que se encontraba "ausente" en el momento

\footnotetext{
77 En 2018 volvió a ser intervenido por Salvador Guzmán Moral, a quien debemos la información sobre el estado de conservación de la obra.

78 Teodoro Falcón, El palacio de San Telmo, (Sevilla: Gever, 1991), pp. 128-133.

79 Letizia Gaeta y Manuel García Luque, "Escultores italianos en España a comienzos del siglo XVIII: novedades sobre Domenico Lemico y Domenico Grasselli", Archivo Español de Arte, 368, (2019), p. 394. ${ }^{80}$ Roda Peña, "Escultura...", p. 171.
} 


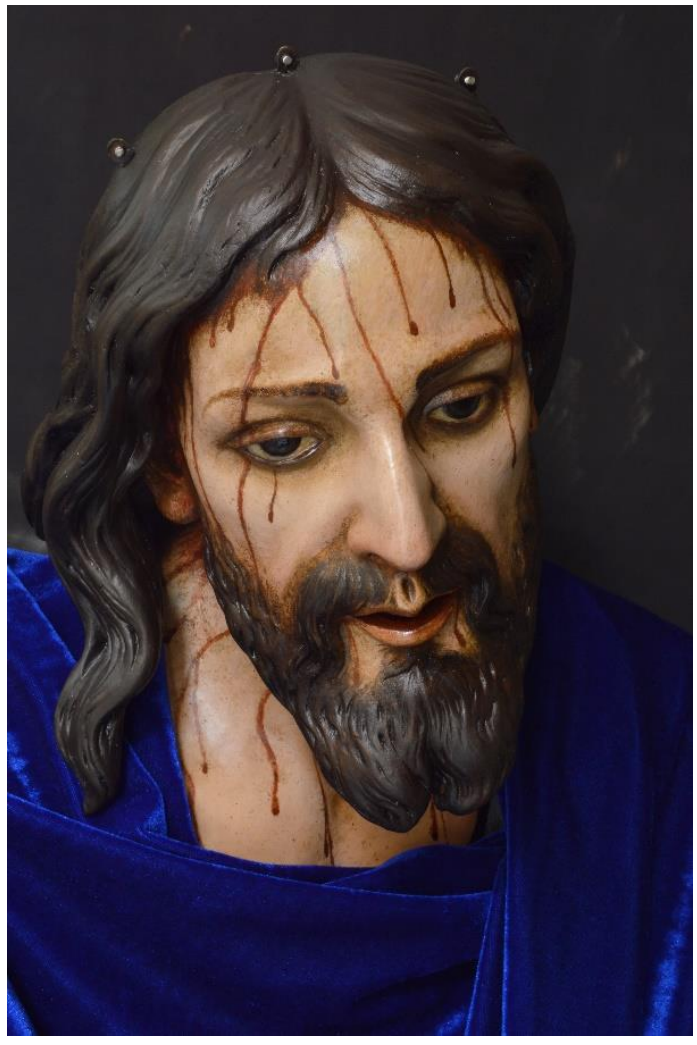

Fig. 7. Miguel de Perea, Jesús Nazareno (detalle), ca. 1730-1732, Baena, iglesia de San Francisco,

CFotografía: Salvador Guzmán

en que el párroco de la Magdalena redactaba el padrón de vecinos ${ }^{81}$. Es difícil precisar si se trataba del escultor sevillano o de un personaje homónimo, pero de lo que no cabe duda es que nuestro personaje se encontraba en la ciudad el 1 de enero de 1739, cuando la catedral le abonó 100 reales a cuenta de cuatro ángeles que estaba tallando para el desaparecido retablo de Nuestra Señora de Guía (Fig. 9) ${ }^{82}$. Su identificación con el sevillano no ofrece dudas, pues la libranza lo menciona expresamente como "Miguel de Perea Ahumada". Los ángeles ya debían estar concluidos en el verano de 1740, aunque parece que hubo cierto desencuentro en el precio, de manera que los cinco ángeles restantes le fueron encargados a un escultor no identificado. Este episodio llevaría a Perea a redactar un memorial que fue leído en cabildo de 29 de junio, buscando recobrar el favor de los canónigos, pero se desconoce si estos accedieron a su pretensión ${ }^{83}$.

${ }^{81}$ Archivo Parroquial de la Magdalena de Granada, Padrón de 1735, Calle del Águila, casa no 497. Junto a él habitan Leonor García, Agustina Barcala y, al parecer, una niña llamada Isabel, que según el párroco "se fue". En el padrón de 1739, Miguel de Perea continúa "ausente" en la casa n 494, donde viven Leonor García, María Montes y una niña llamada María.

82 Archivo de la Catedral de Granada (ACGr), Leg. 289, pieza 2, Pliego de libranzas del mayordomo Francisco González Dávila desde 1 de mayo de 1737, s/f, n. ${ }^{\circ} 34$ : "En $1 .{ }^{\circ}$ de diziembre de 1739 se libraron/r a don Miguel de Ahu Perea y Ahumada, maestro de escultor, zien reales de vellon por quenta de lo que ymporttaren los quatro angeles de escultura que a de hazer para poner en las pilastras que hazen haz a el retablo de Nuestra Señora de la Guia".

83 ACGr, Libro 27 actas capitulares, fol. 102r, cit. en Juan Jesús López-Guadalupe Muñoz, "La Catedral vestida. La arquitectura de retablos", en El libro de la Catedral de Granada, coord. Lázaro Gila Medina, (Cabildo de la Catedral, Granada, 2005), t. I, p. 316. 
Fig. 8. Miguel de Perea, Jesús Nazareno (detalle), ca. 1730-1732, Baena, iglesia de San Francisco, OFotografía: Salvador Guzmán

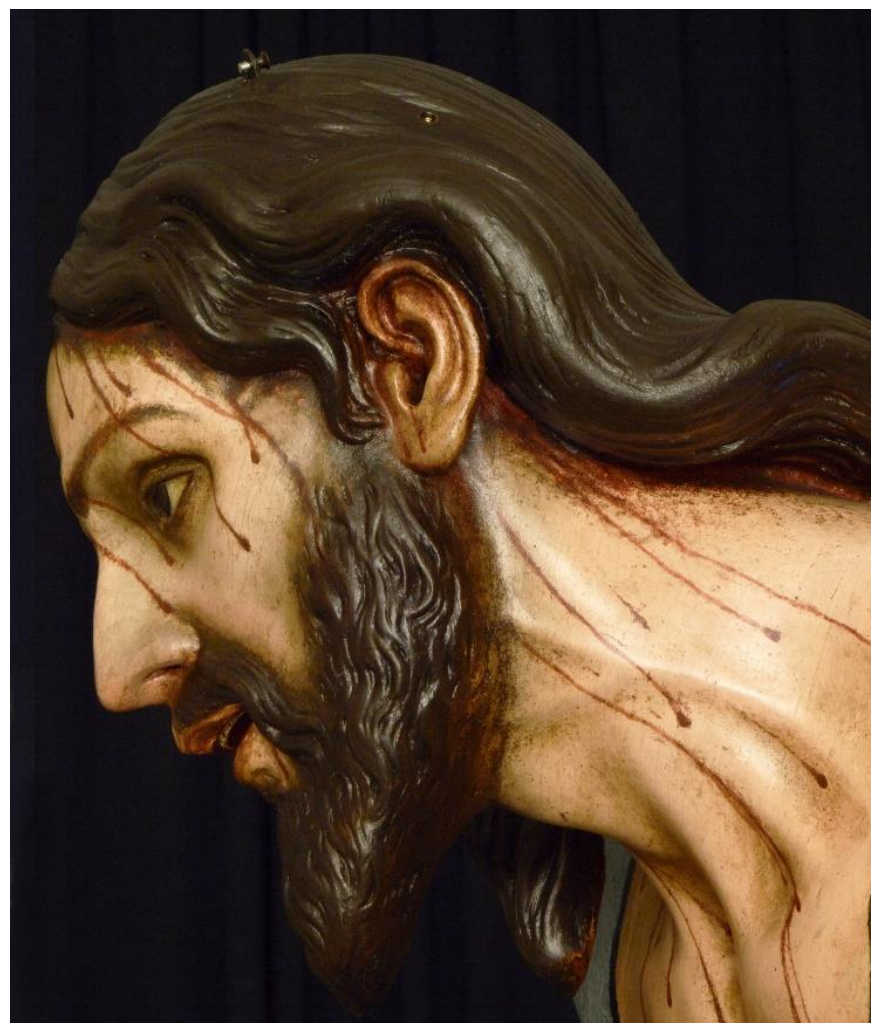

Por estos años, Perea también logró enrolarse en el taller que estaba labrando la portada de la nueva iglesia del hospital de San Juan de Dios, edificada gracias a la munificencia de su General, fray Alonso de Jesús Ortega (1696-1771). Aunque las fuentes no aclaran su exacta cronología, la culminación de su frontispicio marmóreo se suele fechar entre 1739 y $1741^{84}$. Será el cronista de la orden hospitalaria, fray Alonso Parra y Cote, quien se refiera a "Don Miguèl de Pereda" como autor del relieve de mármol de Macael que remata la portada con "la Imagen de el Eterno Padre, figura de medio cuerpo, en accion de bendecir à el Mundo"85 (Fig. 10). Pese a esta antigua identificación, su iconografía corresponde más bien a la de Cristo Salvador del Mundo. Su tipo físico y el tratamiento apelmazado y sinuoso del cabello traen al recuerdo la imagen del Nazareno de Baena, pero hay que reconocer que se trata de una obra de muy segundo orden, que palidece en comparación con el resto del programa figurativo de la portada. Este fue realizado por unos competentes Agustín de Vera Moreno (1699-1760) y José Ramiro Ponce de

\footnotetext{
${ }^{84}$ Juan Jesús López-Guadalupe Muñoz, "En la fábrica de las artes. La escultura en la basílica de San Juan de Dios", en Centesimus Annus: catálogo de la exposición conmemorativa por el I Centenario de la Basílica de la Inmaculada y San Juan de Dios de Granada, com. Adrián Contreras Guerrero (Orden Hospitalaria de San Juan de Dios, Granada, 2016), p. 225.

${ }^{85}$ Fray Alonso Parre y Cote, Desempeño el mas honroso de la obligacion mas fina, y relacion historicopanegirica de las fiestas de dedicacion del magnifico templo de la Purisima Concepcion de Nuestra Señora, [...] de Granada, (Granada: Imp. de Francisco Javier García, 1759), pp. 200-201.
} 


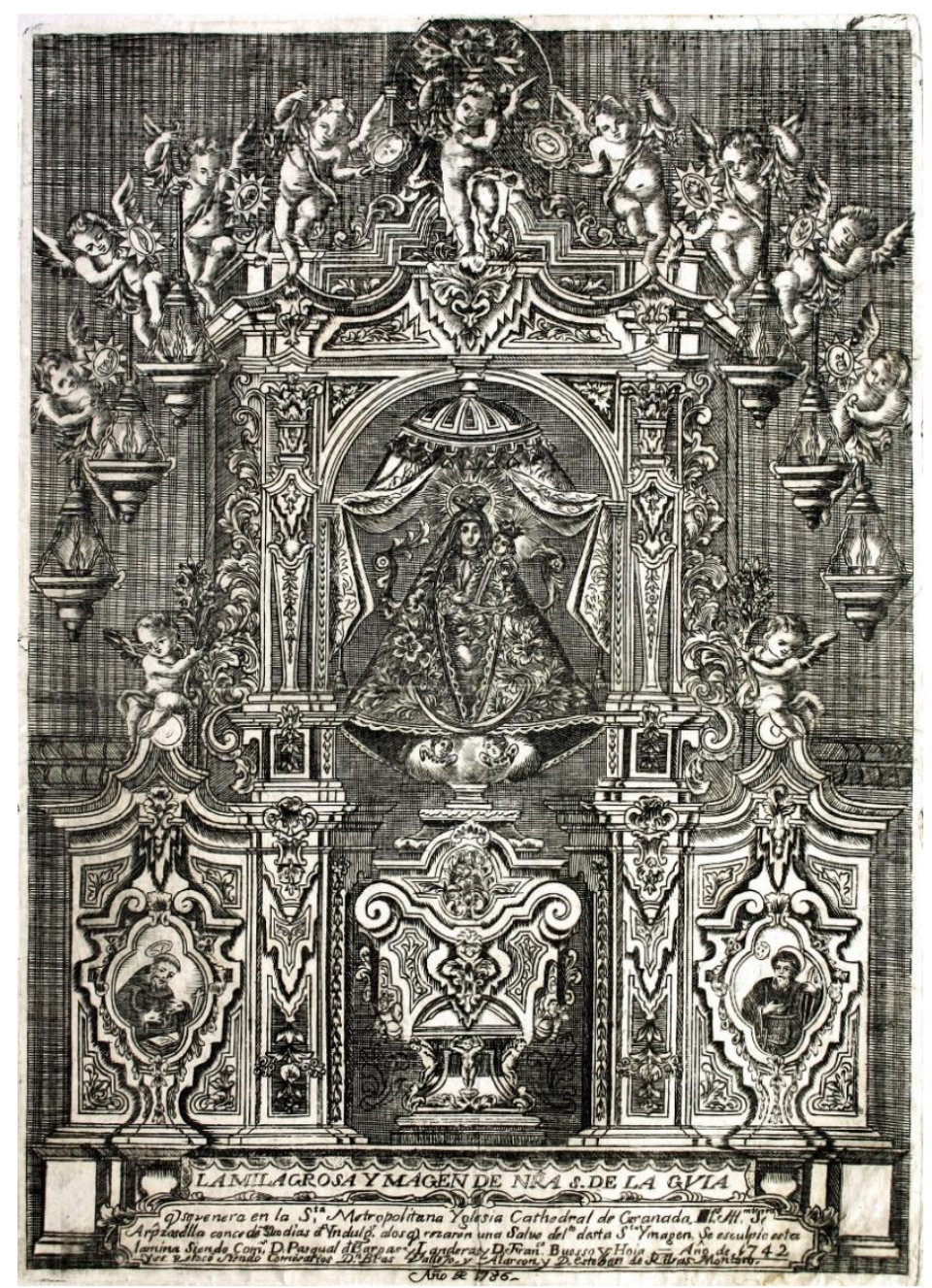

Fig. 9. Anónimo, Retablo de Nuestra Señora de Guía, 1742, calcografía a buril, Granada, Museo Casa de los Tiros.

León (n. 1698), que se encontraban entonces en un momento de pleno esplendor creativo.

Desde luego, la presencia casi anecdótica de Miguel de Perea en las obras de la catedral y la iglesia de San Juan de Dios demuestra que el artista tampoco encontró gran acomodo en el ambiente artístico granadino. Tal vez por ello en 1743 se ofreció a pasar a la Corte cuando se estaban reclutando escultores para la obra del nuevo Palacio Real. A requerimiento de la Corona, el corregidor de Granada había preparado una lista de posibles candidatos locales, en la que incluyó a Torcuato Ruiz del Peral, Agustín de Vera, José Ramiro Ponce y Diego Sánchez Sarabia. El escultor sevillano quedó fuera de esta nómina, pero se apresuró a buscar el amparo de un oidor de la Real Chancillería, Pedro Colón y Larreategui. Al final, el corregidor subsanaría su olvido con la siguiente adenda:

"Don Miguel de Perea y Ahumada vecino de Granada solicita se le de que hazer en la obra de estatuas que se ofrezcan para el Palacio y aña- 


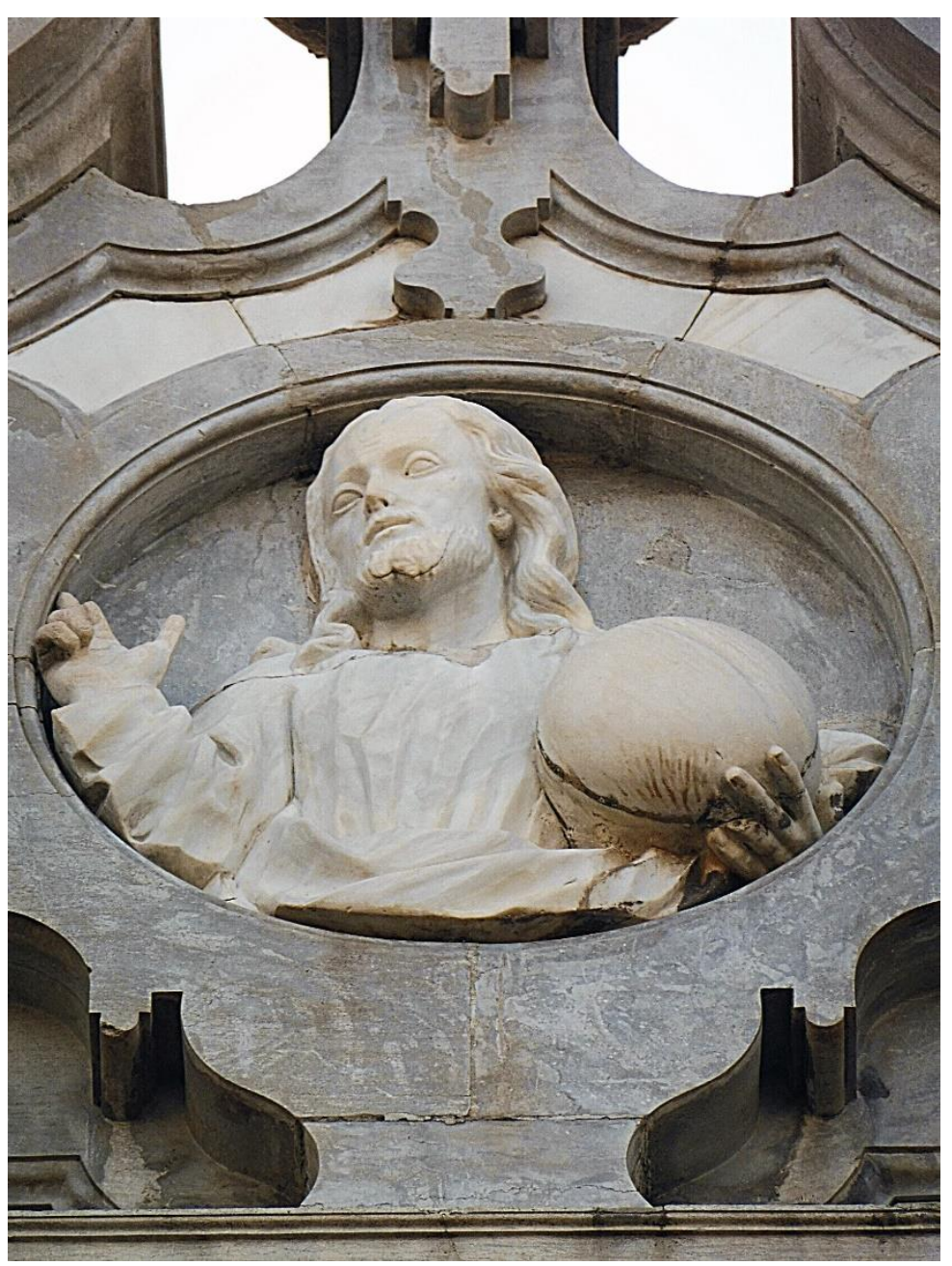

Fig. 10. Miguel de Perea, Salvador del Mundo, ca. 1740, Granada, basílica de San Juan de Dios. OFotografía: Sira Gadea.

de que con el aviso que se le de en esto pasara a este [sic] Corte; es empeño de Don Pedro Colon a quien responde lo que Vuestra Merced me diga"86.

Por el momento, este es el último dato biográfico que tenemos de Perea. Ignoramos si llegó a dar el salto a Madrid, retornó a Sevilla o pasó sus últimos días en Granada, donde quizás falleciera poco tiempo después, pues resulta significativo que tampoco aparezca citado entre los escultores granadinos que a mediados de siglo fueron censados en el ambicioso Catastro de Ensenada ${ }^{87}$. Los datos que hemos ido espigando a lo largo de estas páginas revelan una existencia difícil, salpicada de dificultades que se fueron acentuando con el

${ }^{86}$ Carta fechada a 15 de octubre de 1743. Virginia Albarrán Martín, "Se buscan escultores para el nuevo Palacio Real de Madrid", BSAA Arte, 74 (2008), p. 209.

87 Juan Jesús López Muñoz y Miguel Luis López Muñoz, "Artes y oficios artísticos en Granada a mediados del siglo XVIII", Espacio, Tiempo y Forma, Serie VII, H. a del Arte, 9, (1996), pp. 184-188. 
paso de los años. Al igual que otros muchos artistas de mediano talento, la figura de Perea iría poco a poco apagándose hasta prácticamente acabar relegada a la marginalidad, al no ser capaz de competir ni con los viejos maestros de su generación ni con las jóvenes promesas que, por aquel tiempo, ya comenzaban a despuntar en el panorama escultórico andaluz. 
Bibliografía

Albarrán Martín 2008: Virginia Albarrán Martín, "Se buscan escultores para el nuevo Palacio Real de Madrid", BSAA Arte, 74 (2008), pp. 203-218.

Aranda Doncel 2015: Juan Aranda Doncel, "La Orden Seráfica en tierras cordobesas durante el siglo XVIII: el convento de San Francisco de Baena", Ituci, 5, (2015), pp. 71-101.

Caro Quesada 1992: María Salud Caro Quesada, Noticias de escultura (17001720), (Sevilla: Guadalquivir, 1992).

Ceán Bermúdez 1800: Juan Agustín Ceán Bermúdez, Diccionario Histórico de los más ilustres profesores de las Bellas Artes en España, t. 1 y 4 (Madrid: Imp. de la Viuda de Ibarra, 1800).

Falcón 1991: Teodoro Falcón, El palacio de San Telmo, (Sevilla: Gever, 1991). Gaeta y García Luque 2019: Letizia Gaeta y Manuel García Luque, "Escultores italianos en España a comienzos del siglo XVIII: novedades sobre Domenico Lemico y Domenico Grasselli", Archivo Español de Arte, 368, (2019), pp. 381396.

García 1991: José L. García, "El sevillano Miguel de Perea talló a la imagen de Jesús Nazareno que se venera en la localidad cordobesa de Baena", Boletín de las Cofradías de Sevilla, 386 (noviembre de 1991), pp. 41-42.

García Luque 2017: Manuel García Luque, "La impronta de Murillo en la escultura sevillana del siglo XVIII", en Murillo y su estela en Sevilla, dir. Benito Navarrete Prieto, (Sevilla: ICAS-Ayuntamiento de Sevilla, 2017), pp. 75-89.

García Rosell 2005: Carmen García Rosell, "Benito de Hita y Castillo", en De Jerusalén a Sevilla: la Pasión de Jesús, dir. Manuel Lineros Ríos, t. IV, (Tartessos, Sevilla, 2005), pp. 250-251.

Gestoso Pérez 1899: José Gestoso y Pérez, Ensayo de un diccionario de los artífices que florecieron en esta ciudad de Sevilla desde el siglo XIII hasta el XVIII inclusive, t. I, (Sevilla: La Andalucía Moderna, 1899).

Herrera García 1991: Francisco Javier Herrera García, "Algunas consideraciones sobre el arquitecto de retablos Juan de Valencia", Atrio, 3 (1991), pp. 67-80.

Herrera García 2001: Francisco Javier Herrera García, El retablo sevillano en la primera mitad del siglo XVIII: evolución y difusión del retablo de estípites, (Sevilla: Diputación Provincial, 2001).

Jos López 1986: Mercedes Jos López, La capilla de San Telmo, (Sevilla: Diputación Provincial, 1986). 
Llordén 1973: Andrés Llordén, Convento de San Leandro de Sevilla (notas y documentos para su historia), (Málaga, 1973).

López Muñoz y López Muñoz 1996: Juan Jesús López Muñoz y Miguel Luis López Muñoz, "Artes y oficios artísticos en Granada a mediados del siglo XVIII", Espacio, Tiempo y Forma, Serie VII, H. a del Arte, 9, (1996), pp. 157188.

López-Guadalupe Muñoz 2005: Juan Jesús López-Guadalupe Muñoz, "La Catedral vestida. La arquitectura de retablos", en El libro de la Catedral de Granada, coord. Lázaro Gila Medina, (Cabildo de la Catedral, Granada, 2005), t. I, pp. 491-540.

López-Guadalupe Muñoz 2016: Juan Jesús López-Guadalupe Muñoz, "En la fábrica de las artes. La escultura en la basílica de San Juan de Dios", en Centesimus Annus: catálogo de la exposición conmemorativa por el I Centenario de la Basílica de la Inmaculada y San Juan de Dios de Granada, com. Adrián Contreras Guerrero (Orden Hospitalaria de San Juan de Dios, Granada, 2016), pp. 220-244.

Navarro Lozano 2002: Julián Navarro Lozano, La Compañía de Jesús en el estado de los Duques de Arcos. El Colegio de Marchena (siglos XVI-XVIII), (Granada: Universidad, 2002).

Parra y Cote 1759: Fray Alonso Parre y Cote, Desempeño el mas honroso de la obligacion mas fina, y relacion historico-panegirica de las fiestas de dedicacion del magnifico templo de la Purisima Concepcion de Nuestra Señora [...] de Granada, (Granada: Imp. de Francisco Javier García, 1759).

Quiles García y Cano Rivero 2006: Fernando Quiles García e Ignacio Cano Rivero, Bernardo Lorente Germán y la pintura sevillana de su tiempo (16801759), (Madrid: Fernando Villaverde Ediciones, 2006).

Ravé Prieto 1982: Juan Luis Ravé Prieto, "Jerónimo de Balbás y la sillería coral de San Juan Bautista de Marchena", Revista de arte sevillano, 2, (1982), pp. 29-33.

Ravé Prieto 1986: Juan Luis Ravé Prieto, Arte religioso en Marchena, siglos XV al XIX, (Sevilla: Junta de Andalucía, 1986).

Raya Raya 2009-2013: María Ángeles Raya Raya, "Gaspar Lorenzo de los Cobos", en Diccionario Biográfico Español, (Madrid: Real Academia de la Historia, 2009-2013), ad vocem.

Roda Peña 2014: José Roda Peña, "Escultura en la Baja Andalucía durante el siglo XVIII: síntesis interpretativa e historiografía reciente", Mirabilia Ars, 1, (2014), pp. 162-218.

Rodríguez Becerra 2014: Salvador Rodríguez Becerra, "El franciscano Juan Lasso de la Vega, obispo de Cuba, en Aportaciones al Diccionario Biográfico 
Franciscano de España, Portugal, Iberoamérica y Filipinas, (Córdoba: Asociación Hispánica de Estudios Franciscanos, 2014), pp. 237-250.

Romero García y Heredia Moreno 1973: Purificación Romero García y Ma del Carmen Heredia Moreno, "Noticias sobre el escultor Agustín de Perea", Archivo Hispalense, 171-173, (1973), pp. 273-310.

Romero Torres 2005: José Luis Romero Torres, "Agustín de Perea", en De Jerusalén a Sevilla: la Pasión de Jesús, dir. Manuel Lineros Ríos, t. III (Sevilla: Tartessos, 2005), pp. 200-201.

Romero Torres 2018: José Luis Romero Torres, "Seguidores de Pedro de Mena en Málaga y Antequera", en El triunfo del barroco en la escultura andaluza e hispanoamericana, ed. Lázaro Gila Medina y Francisco Javier Herrera García, (Granada: Universidad de Granada, 2018), pp. 135-158.

Sancho Corbacho 1934: Heliodoro Sancho Corbacho, Arquitectura sevillana del siglo XVIII, (Sevilla: Universidad de Sevilla, 1934).

Torrejón Díaz 1987: Antonio Torrejón Díaz, El escultor José Montes de Oca, (Sevilla: Diputación Provincial, 1987).

Recibido: 22/03/2020

Aceptado: 4/05/2020 
